\title{
ORIGINAL
}

\section{Mechanisms of oxygenation responses to proning and recruitment in COVID-19 pneumonia}

\begin{abstract}
Sandra Rossi ${ }^{1}$, Maria Michela Palumbo ${ }^{2}$, Nicola Sverzellati ${ }^{3}$, Mattia Busana², Laura Malchiodi ${ }^{1}$, Paolo Bresciani ${ }^{3}$, Patrizia Ceccarelli ${ }^{1}$, Emanuele Sani ${ }^{1}$, Federica Romitti ${ }^{2}$, Matteo Bonifazi ${ }^{2}$, Simone Gattarello ${ }^{2,8}$, Irene Steinberg ${ }^{2}$, Paola Palermo ${ }^{2,8}$, Stefano Lazzari ${ }^{2,8}$, Francesca Collino ${ }^{4}$, Massimo Cressoni ${ }^{5}$, Peter Herrmann ${ }^{2}$, Leif Saager ${ }^{2}$, Konrad Meissner ${ }^{2}$, Michael Quintel ${ }^{2}$, Luigi Camporota ${ }^{6}$, John J. Marini ${ }^{7}$ and Luciano Gattinoni ${ }^{2 *}$ (0)
\end{abstract}

(C) 2021 The Author(s)

\begin{abstract}
Purpose: This study aimed at investigating the mechanisms underlying the oxygenation response to proning and recruitment maneuvers in coronavirus disease 2019 (COVID-19) pneumonia.

Methods: Twenty-five patients with COVID-19 pneumonia, at variable times since admission (from 1 to 3 weeks), underwent computed tomography (CT) lung scans, gas-exchange and lung-mechanics measurement in supine and prone positions at $5 \mathrm{cmH}_{2} \mathrm{O}$ and during recruiting maneuver (supine, $35 \mathrm{cmH}_{2} \mathrm{O}$ ). Within the non-aerated tissue, we differentiated the atelectatic and consolidated tissue (recruitable and non-recruitable at $35 \mathrm{cmH}_{2} \mathrm{O}$ of airway pressure). Positive/negative response to proning/recruitment was defined as increase/decrease of $\mathrm{PaO}_{2} / \mathrm{FiO}_{2}$. Apparent perfusion ratio was computed as venous admixture/non aerated tissue fraction.
\end{abstract}

Results: The average values of venous admixture and $\mathrm{PaO}_{2} / \mathrm{FiO}_{2}$ ratio were similar in supine-5 and prone-5. However, the $\mathrm{PaO}_{2} / \mathrm{FiO}_{2}$ changes (increasing in $65 \%$ of the patients and decreasing in 35\%, from supine to prone) correlated with the balance between resolution of dorsal atelectasis and formation of ventral atelectasis $(p=0.002)$. Dorsal consolidated tissue determined this balance, being inversely related with dorsal recruitment $(p=0.012)$. From supine-5

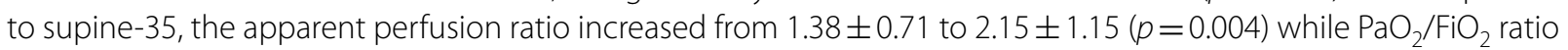
increased in $52 \%$ and decreased in $48 \%$ of patients. Non-responders had consolidated tissue fraction of $0.27 \pm 0.1$ vs. $0.18 \pm 0.1$ in the responding cohort $(p=0.04)$. Consolidated tissue, $\mathrm{PaCO}_{2}$ and respiratory system elastance were higher in patients assessed late (all $p<0.05$ ), suggesting, all together, "fibrotic-like" changes of the lung over time.

Conclusion: The amount of consolidated tissue was higher in patients assessed during the third week and determined the oxygenation responses following pronation and recruitment maneuvers.

Keywords: COVID-19, Prone position, Lung recruitment, ARDS, Mechanical ventilation

\footnotetext{
*Correspondence: gattinoniluciano@gmail.com

${ }^{2}$ Department of Anesthesiology, University Medical Center Göttingen,

Robert-Koch Straße 40, 37075 Göttingen, Germany

Full author information is available at the end of the article

Sandra Rossi and Maria Michela Palumbo contributed equally to this

work.
} 


\section{Introduction}

Patients with acute respiratory distress syndrome (ARDS) from coronavirus disease 2019 (COVID-19) pneumonia [1] present with highly variable pathophysiological characteristics (e.g., respiratory mechanics, responses to prone position and to recruitment maneuver) despite a similar degree of hypoxemia [2,3].

To better understand the relationship between gasexchange, respiratory mechanics, recruitment and response to prone positioning, we studied 25 patients with COVID-19 pneumonia by three computed tomography (CT) scans, taken, for each patient, in a baseline supine condition, in prone position and after a supine recruitment maneuver. Whole lung $\mathrm{CT}$ scans and physiological variables were obtained in prespecified, standardized and identical conditions. Our aim was to investigate the association between anatomical and physiological changes induced by prone positioning, recruitment and their possible uncoupling. We present a conceptual rationale regarding the mechanisms leading to the observed changes.

\section{Materials and methods Study population}

We studied 25 COVID-19 pneumonia patients, admitted in the intensive care unit (ICU) of the Parma University, between March, 18th 2020, and January 29th 2021. The informed consent was obtained using a remote process after discharge. Protocol number of the ethical committee: Comitato Etico Azienda Ospedaliera-Universitaria di Parma, 779/2020/OSS/AOUPR. Although our intention was to consecutively study all admitted COVID-19 patients, this was impossible for logistic reasons (man power required to perform the study and availability of the dedicated CT scan). Within this frame, the patients were not arbitrarily selected, but studied whenever possible. Every patient was measured only at one single time point. Therefore, our analyses are not intended to provide longitudinal "follow-up" but to elucidate the physiological and CT characteristics of patients studied over that timeframe following their hospital admission (see supplementum for further details).

\section{Study protocol}

1. Supine-5: Patients were ventilated (volume control) in supine position, with a tidal volume $6-8 \mathrm{ml} / \mathrm{kg}$, respiratory rate $15-20$ breaths/min, positive end-expiratory pressure (PEEP): $5 \mathrm{cmH}_{2} \mathrm{O}$, and $\mathrm{FiO}_{2}$ adjusted to achieve an oxygen saturation $\left(\mathrm{SpO}_{2}\right)$ target of 92-95\%. Arterial and central venous blood samples were drawn at the same time by two staff members after a 5-min stabilization period [4]. Immediately

\section{Take-home message}

In early COVID-19 pneumonia, the hypoxemia is primarily due to $\mathrm{Va} / \mathrm{Q}$ mismatch and meanwhile, in late stages, to right-to-left shunt. The response to prone position and recruitment decreased along time due to progressive lung consolidation versus atelectasis.

afterward, a chest CT scan was performed at endexpiration while maintaining an airway pressure of 5 $\mathrm{cmH}_{2} \mathrm{O}$.

2. Prone-5: After proning, patients were ventilated as in supine- 5 for $5 \mathrm{~min}$. Arterial and central venous blood samples were drawn as in supine-5. Chest CT scan was performed at end-expiration while maintaining an airway pressure of $5 \mathrm{cmH}_{2} \mathrm{O}$.

3. Supine-35: After turning the patient back to the supine position, the ventilation mode was changed from volume control to pressure control for $2 \mathrm{~min}$, with respiratory rate set at 10 breaths per minute, peak inspiratory pressure of $35 \mathrm{cmH}_{2} \mathrm{O}$, PEEP $5 \mathrm{cmH}_{2} \mathrm{O}$ and $\mathrm{FiO}_{2}$ as in volume control. Arterial and central venous blood samples were drawn as in supine-5. CT scan was performed at an inspiratory airway pressure of $35 \mathrm{cmH}_{2} \mathrm{O}$.

We chose $35 \mathrm{cmH}_{2} \mathrm{O}$ as the maximum airway pressure instead of $45 \mathrm{cmH}_{2} \mathrm{O}$ [5], considering the higher incidence of pneumothorax reported in COVID-19 compared to ARDS from other etiologies [6]. $\mathrm{FiO}_{2}$ was maintained constant throughout the experimental steps.

\section{CT scan analysis}

By quantitative analysis of CT scan [7], we measured the lung anatomical variables as previously described [8]. In addition, comparing the CT scan in supine- 5 and supine-35, we differentiated the atelectasis ("empty" and openable pulmonary units) from consolidation ("full" and non-openable pulmonary units).

\section{Definitions}

Consolidation refers to a substitution of alveolar gases with material, while atelectasis refers to emptying the alveolar units from gases.

We quantified consolidated lung tissue as follows:

$$
\text { Consolidated tissue }=\text { Non aerated tissue } 35 \text {. }
$$

Therefore, we considered as consolidated, the fraction of non-aerated tissue which could not regain aeration at $35 \mathrm{cmH}_{2} \mathrm{O}$ of airway pressure, i.e., the amount of aerated tissue after the recruitment maneuver.

We quantified atelectatic lung tissue and atelectatic tissue fraction as follows: 
Atelectatic tissue $=$ non aerated tissue $_{5}-$ non aerated tissue 35 ,

Atelectatic tissue fraction $=\frac{\text { non aerated tissue }}{5-\text { non aerated tissue }_{35}}$.

To investigate the relationship between the non-aerated tissue fraction and venous admixture, we calculated the "apparent perfusion ratio" [9] which expresses the ratio between the perfusion of each gram of non-aerated tissue and the perfusion of each gram of aerated tissue (see supplement for derivation).

$$
\text { Apparent perfusion ratio }=\frac{\mathrm{Qva} / \mathrm{Q}}{\text { Non areated tissue fraction }},
$$

where $\mathrm{Qva} / \mathrm{Q}$ is the venous admixture according to Riley's model [10].

A value of apparent perfusion ration $=1$ indicates equal perfusion in non-aerated and aerated tissue, $<1$ indicates relative hypoperfusion of the former, and $>1$ its relative hyperperfusion.

\section{Statistical analysis}

Data are presented as mean \pm standard deviation or median and interquartile range, as appropriate. The chisquare test or Fisher's exact test of independence was used for categorical variables, $T$-Test for continuous variables and non-parametric test (Kruskal-Wallis test) in case of non-normal distribution. Linear regression was used to assess the relationship between continuous variables. A One-way ANOVA test for repeated measure was used to account for the repeated measures design and Tukey post-hoc test for multiple comparisons. Two-tailed $p$ values $<0.05$ were considered statistically significant. Rstudio for Statistical Computing with the Tidyverse package collection was used for analysis.

\section{Results}

\section{Study population}

As shown in Table 1, the average time between hospital admission and study enrollment was $11 \pm 6$ days (from 3 to 24 days). At the time of study, the majority of the patients satisfied the criteria of moderate ARDS, according to Berlin criteria, and the overall hospital mortality was $32 \%$. All patients were routinely treated with prone position.

\section{Anatomical and physiological variables in supine-5, prone- 5 and supine- 35}

The most relevant anatomical and physiological variables we measured in prone-5, supine- 5 and supine- 35 are shown in Table 2. As indicated, there were only few significant changes with repositioning from supine- 5 to prone-5. In particular, the amounts of gas and the fractions of normally, poorly, and non-aerated tissue were similar for prone- 5 and supine- 5 , while the atelectatic tissue fraction significantly decreased from 13 to $8 \%$. Gas-exchange variables were similar between supine-5, and prone-5, while the respiratory system mechanics worsened from supine- 5 to prone- 5 due to an increase of respiratory system elastance, likely due to the increased stiffness of the anterior chest wall [11]. $\mathrm{pH}$ was slightly but significantly higher in prone- 5 than in the other two conditions.

To reach an inspiratory airway pressure of $35 \mathrm{cmH}_{2} \mathrm{O}$ during the recruitment maneuver required the use of significantly larger tidal volume and driving pressures in supine- 35 , compared to supine- 5 and prone- 5 . Therefore, the gas volume, the overinflated and the normally aerated tissue fractions were higher in supine-35, compared to supine- 5 and prone- 5 , while the poorly and the non-aerated tissue fractions were significantly lower. The respiratory system elastance decreased significantly in supine-35, reflecting the reduction in non-aerated tissue. Regardless the overall improvement of tissue aeration, however, the gas-exchange variables did not improve and were similar to prone- 5 and supine- 5 . In addition, the ventilatory ratio significantly deteriorated in supine- 35 .

The arterio-venous (a-v) $\mathrm{O}_{2}$ content difference, and the central venous oxygen saturation, considered here as a surrogate of cardiac output, were similar in the three conditions we tested. However, during the supine-35, a slight but significant decrease of mean arterial pressure and heart rate was observed. Therefore, changes in cardiac output cannot be excluded. The apparent perfusion ratio, an indicator of the perfusion of non-aerated tissue relative to the perfusion of

\section{Table 1 Clinical characteristics of the study cohort}

\begin{tabular}{|c|c|}
\hline Variables & Population $(n=25)$ \\
\hline Female $(n-\%)$ & $5(20)$ \\
\hline Age (years) & $62.6 \pm 8.4$ \\
\hline Height (cm) & $171 \pm 9.7$ \\
\hline Body mass index-BMI $\left(\mathrm{kg} / \mathrm{m}^{2}\right)$ & $28.9 \pm 4.3$ \\
\hline Simplified acute physiology score II & $36.7 \pm 10.3$ \\
\hline Days from symptoms onset to study day & $18.2 \pm 8$ \\
\hline Days from hospital admission to study day & $11 \pm 6$ \\
\hline $\begin{array}{l}\text { Days of non-invasive support prior to mechanical } \\
\text { ventilation }\end{array}$ & $5.5 \pm 3.9$ \\
\hline Days of mechanical ventilation to study day & $4.9 \pm 4.7$ \\
\hline \multicolumn{2}{|l|}{ Berlin ARDS category at the study day- $n(\%)$} \\
\hline - Mild & $2(8)$ \\
\hline - Moderate & $16(64)$ \\
\hline - Severe & $7(28)$ \\
\hline Hospital length of stay & $60.7 \pm 32$ \\
\hline Intensive care unit length of stay & $27.8 \pm 18.15$ \\
\hline Mortality (n-\%) & $8(32)$ \\
\hline
\end{tabular}


Table 2 Physio-anatomical variables of the study cohort

\begin{tabular}{|c|c|c|c|c|}
\hline Study variables & Supine $-5 \mathrm{cmH}_{2} \mathrm{O}$ & Prone $-5 \mathrm{cmH}_{2} \mathrm{O}$ & Supine $-35 \mathrm{cmH}_{2} \mathrm{O}$ & $p$ value \\
\hline \multicolumn{5}{|l|}{ Computed tomography scan } \\
\hline Total tissue mass (g) & $1291 \pm 380$ & $1304 \pm 392$ & $1324 \pm 385$ & 0.9 \\
\hline Total gas volume (ml) & $1101 \pm 647$ & $1151 \pm 696$ & $2107 \pm 969^{a b}$ & $<0.001$ \\
\hline Overinflated tissue/total tissue mass (\%) & $0.7 \pm 1.4$ & $0.7 \pm 1.3$ & $2.3 \pm 3.3^{a}$ & 0.002 \\
\hline Normally inflated tissue/total tissue mass (\%) & $26 \pm 13$ & $27 \pm 14$ & $43 \pm 13^{a b}$ & $<0.001$ \\
\hline Poorly inflated tissue/total tissue mass (\%) & $37 \pm 8$ & $39 \pm 10$ & $32 \pm 8^{b}$ & 0.02 \\
\hline Non-areated tissue/total tissue mass (\%) & $36 \pm 14$ & $32 \pm 15$ & $23 \pm 11^{a b}$ & 0.001 \\
\hline Atelectatic tissue/total tissue mass (\%) & $13 \pm 11$ & $8 \pm 11$ & $0 \pm 0$ & 0.011 \\
\hline Consolidated tissue/total tissue mass (\%) & $23 \pm 11$ & $24 \pm 11$ & $23 \pm 11$ & 0.85 \\
\hline Consolidated tissue/non aerated tissue (\%) & $67.2 \pm 23.3$ & $78.8 \pm 28.9$ & $100 \pm 0$ & 0.016 \\
\hline \multicolumn{5}{|l|}{ Gas exchange } \\
\hline $\mathrm{FiO}_{2}$ & $0.72 \pm 0.19$ & $0.72 \pm 0.19$ & $0.72 \pm 0.19$ & 0.99 \\
\hline $\mathrm{PaO}_{2} / \mathrm{FiO}_{2}(\mathrm{mmHg})$ & $129.9 \pm 54.98$ & $144.3 \pm 59.6$ & $147.2 \pm 75.6$ & 0.7 \\
\hline Arterial hemoglobin oxygen saturation (\%) & $92.5 \pm 7.5$ & $93.6 \pm 7.5$ & $94.16 \pm 6.63$ & 0.5 \\
\hline Venous admixture $\left(\mathrm{Q}_{\mathrm{VA}} / \mathrm{Q}\right),(\%)$ & $46 \pm 2$ & $42 \pm 16$ & $41 \pm 18$ & 0.7 \\
\hline $\mathrm{PaCO}_{2}(\mathrm{mmHg})$ & $51.2 \pm 9.9$ & $49.4 \pm 11.6$ & $45.9 \pm 12.3$ & 0.1 \\
\hline $\mathrm{pH}$ & $7.4 \pm 0.05$ & $7.4 \pm 0.04$ & $7.44 \pm 0.07$ & 0.04 \\
\hline Base excess (mmol/l) & $5.7 \pm 3.8$ & $5.76 \pm 3.9$ & $5.8 \pm 3.9$ & 0.96 \\
\hline End-tidal $\mathrm{CO}_{2}(\mathrm{mmHg})$ & $42 \pm 9.7$ & $39.8 \pm 8.1$ & $38.4 \pm 11.2$ & 0.43 \\
\hline Ventilatory ratio & $1.56 \pm 0.51$ & $1.44 \pm 0.59$ & $1.96 \pm 0.69^{b}$ & 0.005 \\
\hline \multicolumn{5}{|l|}{ Respiratory mechanics } \\
\hline Minute ventilation (I/min) & $8.3 \pm 1.9$ & $8 \pm 2.3$ & $12.5 \pm 5^{\mathrm{ab}}$ & $<0.001$ \\
\hline Tidal volume (ml/kg) & $6.6 \pm 1.1$ & $6.4 \pm 1.5$ & $16.5 \pm 5.4^{\mathrm{ab}}$ & $<0.001$ \\
\hline Peak pressure $\left(\mathrm{cmH}_{2} \mathrm{O}\right)$ & $21.4 \pm 4.3$ & $26.7 \pm 6$ & $36.2 \pm 2.2^{a b c}$ & $<0.001$ \\
\hline Plateau pressure $\left(\mathrm{cmH}_{2} \mathrm{O}\right)$ & $20.5 \pm 4.2$ & $25.4 \pm 6$ & $35 \pm 2^{a b c}$ & $<0.001$ \\
\hline Driving pressure $\left(\mathrm{cmH}_{2} \mathrm{O}\right)$ & $15.5 \pm 4.2$ & $20.3 \pm 6$ & $30.2 \pm 2.2^{a b c}$ & $<0.001$ \\
\hline Respiratory system elastance $\left(\mathrm{cmH}_{2} \mathrm{O} / \mathrm{ml}\right)$ & $35.1 \pm 11.3$ & $47.9 \pm 20$ & $29.8 \pm 11.3^{b c}$ & $<0.001$ \\
\hline \multicolumn{5}{|l|}{ Hemodinamics } \\
\hline$(a-v) \mathrm{O}_{2}$ difference $(\mathrm{ml} / 100 \mathrm{ml})$ & $2.5 \pm 1.1$ & $2.66 \pm 0.87$ & $2.7 \pm 1$ & 0.75 \\
\hline $\mathrm{CaO}_{2}-$ Arterial oxygen content (ml/dl) & $14.9 \pm 2.5$ & $15 \pm 2.8$ & $15 \pm 2.5$ & 0.9 \\
\hline $\mathrm{CvO}_{2}-$ Venous oxygen content $(\mathrm{ml} / \mathrm{dl})$ & $12.3 \pm 2.5$ & $12.3 \pm 2.6$ & $12.3 \pm 2.4$ & 0.99 \\
\hline Central venous hemoglobin oxygen saturation (\%) & $76.9 \pm 8$ & $77.8 \pm 8.3$ & $77.6 \pm 8.2$ & 0.96 \\
\hline Apparent perfusion ratio & $1.38 \pm 0.71$ & $1.42 \pm 0.56$ & $2.15 \pm 1.15^{\mathrm{ab}}$ & 0.02 \\
\hline
\end{tabular}

Analysis of the groups based on the three different steps. Overinflated, normally aerated, poorly aerated, non-aerated tissue fraction, atelectatic and consolidated (\%) fractions are expressed as percentages of tissues on the total tissue mass. Normal distribution for continuous variables has been tested with the Shapiro-Wilk test. Differences between groups are tested with one-way repeated measure ANOVA, in case of normally distributed variables, and Tukey post-hoc test for multiple comparisons, while non-normally distributed variables are tested with the non-parametric Kruskal-Wallis test. In the table

a $p<0.05$ on ANOVA: post_hoc test significant between supine- 5 and supine-35

b $p<0.05$ on ANOVA: post_hoc test significant between supine-35 and prone-5

c $p<0.05$ on ANOVA: post_hoc test significant between prone- 5 and supine- 5

aerated tissue [9], almost doubled in supine-35, compared to supine-5 and prone-5.

\section{Prone position: anatomical and physiological response} Repositioning from supine-5 to prone-5 caused a significant change in lung shape. Indeed, in prone position the fraction of the total tissue mass in the upper half of non-dependent lung was $61.5 \pm 0.05 \%$, almost double that in supine position $(32 \pm 0.04 \%, p<0.001)$. The tissue distribution is represented in Fig. 1, upper panels. As shown (panel $\mathrm{C}$ ), in prone position the non-aerated tissue increased in the ventral levels of the lung while it decreased in the dorsal ones. In other words, in prone position new ventral atelectasis were formed, while the dorsal atelectasis present in supine position regained aeration and disappeared. The formation and dissolution of atelectasis was a function of the changes in hydrostatic superimposed pressure (see Fig. E1). Indeed, in prone 


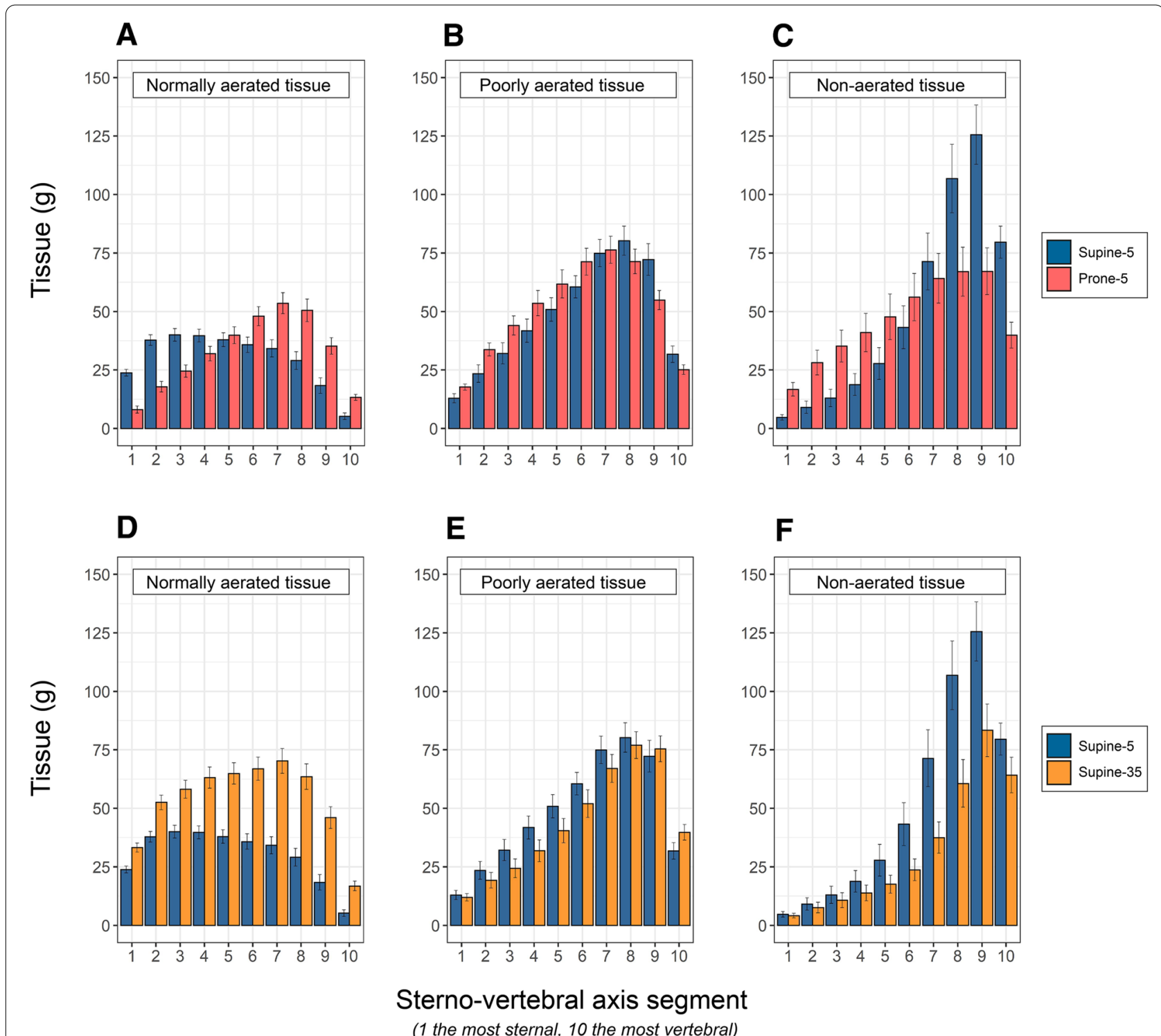

Fig. 1 Upper panels: Tissue mass distributions of normally aerated $(\mathbf{A})$, poorly aerated $(\mathbf{B})$ and non-aerated tissues $(\mathbf{C})$, as a function of lung segments (mean \pm se) along the sterno (segment 1)-vertebral (segment 10) axis, in supine-5 (blue) and prone-5 positions (red). A The normally aerated tissue, in supine position, was more distributed in the ventral regions (segments 1 to 5, $179 \mathrm{gr} \pm 56, \mathrm{SD}$ ) and decreased in dorsal regions (segments 5 to $10,122 \mathrm{gr} \pm 74, \mathrm{SD})(p<0.001)$. In prone position, in contrast, it was less distributed in the ventral regions (segments 1 to $5,122 \mathrm{gr} \pm 60$, SD) and more in dorsal regions (segments 5 to 10, $200 \mathrm{gr} \pm 84$, SD) $(p<0.001)$. B The poorly aerated tissue, in supine position, was less distributed in the ventral regions (segments 1 to 5, $161 \mathrm{gr} \pm 94, \mathrm{SD}$ ) and increased in dorsal regions (segments 5 to 10, $320 \mathrm{gr} \pm 112$, SD) $(p<0.001)$. Similarly, in prone position it was less distributed in the ventral regions (segments 1 to 5, $211 \mathrm{gr} \pm 87$, SD) and more in dorsal regions (segments 5 to 10, 298 gr \pm 101 , SD) $(p<0.001)$. C: the non-aerated tissue, in supine position, was markedly less distributed in the ventral regions (segments 1 to 5, 73 gr \pm 92, SD) than in dorsal regions (segments 5 to $10,427 \mathrm{gr} \pm 254, \mathrm{SD})(p<0.001)$. Similarly, in prone position it was less distributed in the ventral regions (segments 1 to 5, $169 \mathrm{gr} \pm 154, \mathrm{SD}$ ) and more in dorsal regions (segments 5 to 10, $294 \mathrm{gr} \pm 209, \mathrm{SD})(p<0.001)$. Note that differences in column heights between prone and supine from 1 to 5 indicate the formation of ventral atelectasis, while from segments 6 to 10 it indicates the disappearance of the dorsal atelectasis. Lower panels: Tissue mass distributions of normally aerated (A), poorly aerated $(\mathbf{B})$ and non-aerated tissues $(\mathbf{C})$, as a function of lung segments (mean \pm se) along the sterno (segment 1)-vertebral (segment 10) axis, in supine-5 (blue) and supine-35 (okra yellow). D The normally aerated tissue was greater in supine- 35 than in supine-5, in each of the ten segments (total normally aerated tissue 535 gr \pm 171 SD vs 302 $\mathrm{gr} \pm 116 \mathrm{SD}$, respectively, $p<0.001)$. E The poorly aerated tissue, was similar in supine- 35 and in supine- 5 and similarly distributed in each of the ten segments (total poorly aerated tissue $439 \mathrm{gr} \pm 189$ SD vs $481 \mathrm{gr} \pm 154$ SD, respectively). F: the non-aerated tissue was greater in supine-5 than in supine-35, in each of the ten segments (total non-aerated tissue $499 \mathrm{gr} \pm 328$ SD vs $323 \mathrm{gr} \pm 249$ SD, respectively, $p<0.05$ ). Note that the height of the red columns represents the consolidated tissue and the difference between supine- 5 and supine- 35 columns represents the atelectatic tissue prevalent in the dorsal lung segments (from 5 to 10) 
position, the ventral atelectasis appeared because of the increased compression exerted by the weight of the lung above, while the dorsal atelectasis disappeared as the compression was released. As opposed to the non-aerated tissue, the well-aerated tissue increased in the dorsal regions during prone positioning and decreased in the ventral zones, compared to supine (Fig. 1, panel A).

Although the differences in $\mathrm{PaO}_{2} / \mathrm{FiO}_{2}$ and $\mathrm{Q}_{\mathrm{VA}} / \mathrm{Q}$, between supine- 5 and prone- 5 , did not reach statistical significance (see Table 2), their changes when going from supine to prone position were independently correlated both with the changes of the non-aerated tissues (i.e., the balance between "old" dorsal atelectasis, which disappeared, and "new" ventral atelectasis, which appeared) and with the changes of its apparent perfusion ratios (see Fig. E2 for the individual responses and, see Figs. E3 and E4 for regressions). It is worth noting that the consolidated tissue maintains its anatomical location (either dorsal or ventral) independently on the position (Fig. E5) and this carries three consequences: first, the dorsal consolidated tissue does not reopen and cannot contribute to improve oxygenation. Second, the ventral atelectasis anyway develops to the increased compressive forces $(p=0.012$, Fig. E6). Last, the final result is a greater venous admixture in prone- 5 than in supine- 5 ( $p=0.018$, Fig. E7). Thirty-five percent of the patients experienced a negative $\mathrm{PaO}_{2} / \mathrm{FiO}_{2}$ difference in the prone position relative to the supine position, and $65 \%$ could be classified as non-responders, having undergone a $\mathrm{PaO}_{2} / \mathrm{FiO}_{2}$ increase $\leq 20 \mathrm{mmHg}$ [12].

\section{Recruitment: anatomical and physiological response}

The tissue distributions along the sterno-vertebral axis in supine- 5 and supine- 35 are represented in Fig. 1, lower panels. As shown in panel D, the normally aerated tissue in supine-35 increased remarkably at each lung level compared to supine-5. The poorly aerated tissue (Panel E) was slightly more prevalent in supine- 5 and decreased in supine-35, while the non-aerated tissue (Panel F) significantly decreased, primarily in the dorsal dependent regions. In the different levels from 1 to 10 , the differences in the heights of the non-aerated tissue of supine- 5 and 35 columns quantify the amount of atelectatic tissue which disappeared at $35 \mathrm{cmH}_{2} \mathrm{O}$ of inspiratory pressure $(176.8 \pm 187 \mathrm{~g} /$ patient). Although the differences in $\mathrm{PaO}_{2} / \mathrm{FiO}_{2}$ and $\mathrm{Q}_{\mathrm{VA}} / \mathrm{Q}$, between supine-5 and supine-35, did not reach statistical significance (see Table 2), the changes of $\mathrm{Q}_{\mathrm{VA}} / \mathrm{Q}$ when increasing the airway pressure from 5 to $35 \mathrm{cmH}_{2} \mathrm{O}$, were correlated with the changes of the non-aerated tissues (i.e., the re-aeration of the atelectasis) (see Fig. E8), while the perfusion ratio of consolidated tissue increased from 1.4 in supine-5, to 2.15 in supine-35 $(p<0.001)$. Of note, $48 \%$ of the patients experienced a decrease in $\mathrm{PaO}_{2} / \mathrm{FiO}_{2}$, during the recruitment maneuver (see Table E1 in supplement and Fig. E9 for the individual responses).

\section{Anatomical/physiological variables and time}

In Fig. 2 we illustrate the distribution of consolidated and atelectatic tissues in patients studied during the first-, the second- and the third week following their hospital admission. As shown, the consolidated tissue was lower in patients studied during the first week than in patients studied in the third week from hospital admission, and its fraction significantly correlated with the time elapsed between hospital admission and the study day $(p=0.013$, Fig. E10). This increase in consolidation was paralleled by a similar increase of the respiratory system elastance $(p=0.03$, Fig. E11). In contrast, the amount of atelectatic tissue did not change significantly with elapsed time.

The differences between anatomical, physiological and clinical variables recorded in the three different weeks are presented in Table 3. As shown, the $\mathrm{PaO}_{2} / \mathrm{FiO}_{2}$ variables were similar at entry to hospital and remained similar throughout the weeks. In contrast, the $\mathrm{PaCO}_{2}$ and the ventilatory ratio were higher if the time elapsed from hospital admission to the day of study was greater $(p=0.008$ and $p=0.01$, Fig. E12).

Although only the consolidated tissue was significantly greater over the three weeks, there was a clear tendency to worsening of all the other anatomical variables explored. Of note, the frequency of patients who showed a negative delta $\mathrm{PaO}_{2} / \mathrm{FiO}_{2}$ to prone positioning and to recruitment increased progressively over time. Similarly, the $\mathrm{PaCO}_{2}$ response to prone positioning $(p=0.047)$ and recruitment $(p=0.016)$, deteriorated significantly with the time elapsed from hospital admission to CT scan (Fig. E13).

\section{Discussion}

\section{Response to the prone position}

Several phenomena occur contemporaneously when patients are shifted from supine to the prone position, as a more homogeneous distribution of tissue mass, gas-totissue ratio and an increase in chest wall elastance [13]. All these elements are of great relevance in providing a better distribution of stress and strain and, therefore, contributed to lung protection [14]. As far as oxygenation is concerned, however, the primary phenomenon is the balance between the release of dorsal atelectasis and its formation in the ventral zones. This density "redistribution" has been consistently observed in early ARDS $[15,16]$, where the tissue collapse in the ventral regions is associated with a near total re-expansion of collapsed dorsal lung units (see Fig. E14, panel A). However, if a significant amount of consolidated tissue is present in 


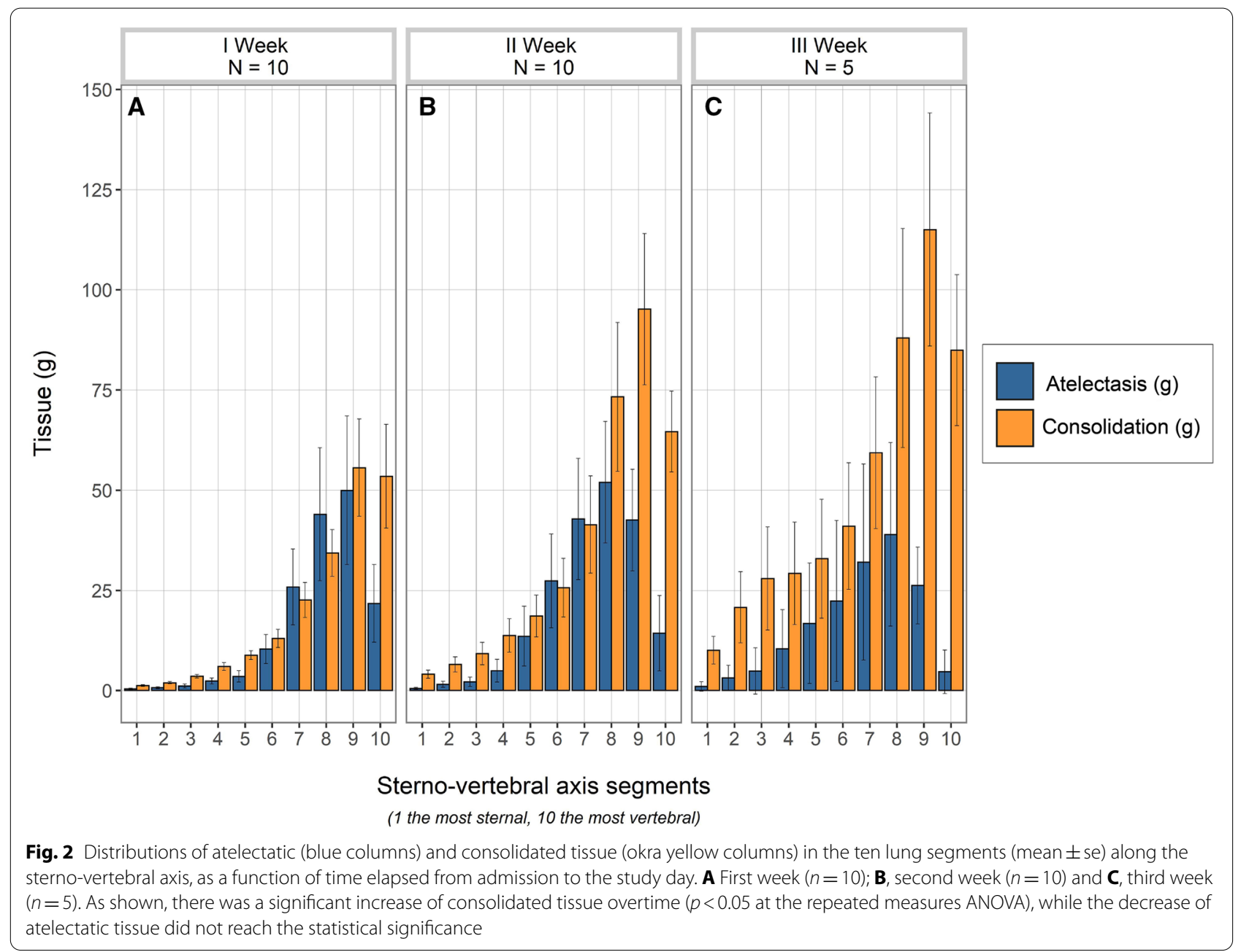

dorsal regions, as in our patients with COVID-19, the dorsal de-collapse in prone is very limited as the irreversibly consolidated tissue cannot reopen (see Fig. E14, panel B) while the ventral regions still bear the weight of the dorsal regions situated above them. This compression (i.e., the superimposed pressure) determines the formation of ventral atelectasis. Therefore, the lesser or greater amount of consolidated tissue within the non-aerated tissue in dorsal lung regions accounts for the huge variation of recruited/derecruited tissue between prone- 5 and supine- 5 positions, ranging from +225 to $-120 \mathrm{~g}$ (model in Fig. E15).

Although the prone position is largely used in COVID19 to improve oxygenation, in our population we found that Delta $\mathrm{PaO}_{2} / \mathrm{FiO}_{2}$ was negative in $35 \%$ of the patients when in the prone position, and 65\% could be classified as a "non-responder", according to the previously used threshold of Delta $\mathrm{PaO}_{2} / \mathrm{FiO}_{2}$ (prone-supine) $\leq 20 \mathrm{mmHg}$ [12]. We found two variables that were independently associated with the position-related $\mathrm{PaO}_{2} / \mathrm{FiO}_{2}$ changes, i.e., recruitment/derecruitment (the balance between dorsal and ventral atelectasis) and the changes of the apparent perfusion ratio. In experimental models [17$19]$ and in normal subjects [20,21], the perfusion does not change significantly with position, and the recruitment/derecruitment ratio fully accounts for the changes of $\mathrm{PaO}_{2} / \mathrm{FiO}_{2}$. In COVID-19 patients, however, where the loss of perfusion control is a characteristic trait [22-25], we found that the changes of the perfusion ratio contribute to the changes of $\mathrm{PaO}_{2} / \mathrm{FiO}_{2}$. Indeed, an increase of perfusion ratio, i.e., a gravity dependent increase of perfusion of the ventral atelectasis dampens or reverses any $\mathrm{PaO}_{2} / \mathrm{FiO}_{2}$ rise due to recruitment.

\section{Response to recruitment}

Several studies reported recruitability and response to PEEP increase in COVID-19 patients, by using different techniques for recruitment assessment, from CT scan [26] to recruitment/inflation ratio [27]. Although the responses were variable, the majority of the studies 
Table 3 Physio-anatomical variables and time recorded at Supine-5

\begin{tabular}{|c|c|c|c|c|}
\hline Study variables (at the study day, supine-5) & I week & II week & III week & $p$ value \\
\hline \multicolumn{5}{|l|}{ Gas exchange } \\
\hline $\mathrm{PaO}_{2} / \mathrm{FiO}_{2}$ at the study day $(\mathrm{mmHg})$ & $128 \pm 37$ & $139 \pm 70$ & $117 \pm 61$ & 0.77 \\
\hline $\mathrm{Q}_{\mathrm{VA}} / \mathrm{Q}_{\top}$ at the study day (\%) & $49 \pm 22$ & $43 \pm 20$ & $48 \pm 22$ & 0.8 \\
\hline $\mathrm{PaCO}_{2}$ at the study day $(\mathrm{mmHg})$ & $48 \pm 6$ & $51 \pm 10$ & $58 \pm 14$ & 0.39 \\
\hline Ventilatory ratio & $1.4 \pm 0.33$ & $1.5 \pm 0.5$ & $2 \pm 0.6^{\mathrm{cd}}$ & 0.03 \\
\hline \multicolumn{5}{|l|}{ Respiratory mechanics } \\
\hline Tidal volume (ml/kg) & $469 \pm 55$ & $447 \pm 79$ & $426 \pm 82$ & 0.54 \\
\hline Minute ventilation (I/min) & $7.8 \pm 1.2$ & $8 \pm 2$ & $9.8 \pm 2$ & 0.13 \\
\hline Plateau pressure $\left(\mathrm{cmH}_{2} \mathrm{O}\right)$ & $20.4 \pm 4$ & $19 \pm 3.7$ & $23 \pm 5$ & 0.2 \\
\hline Driving pressure $\left(\mathrm{cmH}_{2} \mathrm{O}\right)$ & $15.3 \pm 4$ & $14.2 \pm 3.7$ & $18.2 \pm 5$ & 0.2 \\
\hline Respiratory system elastance $\left(\mathrm{cmH}_{2} \mathrm{O} / \mathrm{ml}\right)$ & $32 \pm 6$ & $33 \pm 13$ & $44 \pm 13$ & 0.14 \\
\hline \multicolumn{5}{|l|}{ Hemodynamics } \\
\hline $\mathrm{CaO}_{2}-$ Arterial oxygen content (ml/dl) & $16 \pm 1.8$ & $15 \pm 2.7$ & $12 \pm 1$ & 0.01 \\
\hline $\mathrm{CvO}_{2}-$ Venous oxygen content $(\mathrm{ml} / \mathrm{dl})$ & $13.5 \pm 2.4$ & $12.5 \pm 2.5$ & $9.8 \pm 0.8$ & 0.02 \\
\hline Central venous hemoglobin oxygen saturation (\%) & $78 \pm 7.7$ & $77 \pm 8.7$ & $74 \pm 8$ & 0.7 \\
\hline Apparent perfusion ratio & $1.82 \pm 0.96$ & $1.09 \pm 0.29$ & $1.12 \pm 0.2$ & 0.12 \\
\hline \multicolumn{5}{|l|}{ Computed tomography scan } \\
\hline Total tissue mass (g) & $1190 \pm 309$ & $1302 \pm 383$ & $1471 \pm 504$ & 0.42 \\
\hline Total gas volume (ml) & $1279 \pm 750$ & $1019 \pm 589$ & $906 \pm 564$ & 0.3 \\
\hline Consolidated tissue/total tissue mass (\%) & $16 \pm 7$ & $25 \pm 11$ & $31 \pm 10^{c}$ & 0.02 \\
\hline Atelectatic tissue/total tissue mass (\%) & $12 \pm 11$ & $14 \pm 11$ & $10 \pm 13$ & 0.55 \\
\hline \multicolumn{5}{|l|}{ Response to proning and recruitment } \\
\hline Patients_-non responders to prone (\%) ${ }^{\mathrm{a}}$ & 44 & 67 & 100 & 0.58 \\
\hline Patients—decrease $\mathrm{PaO}_{2} / \mathrm{FiO}_{2}$ during recruitment (\%) & 20 & 50 & 100 & 0.014 \\
\hline Total non-invasive ventilatory support before intubation (days) & $2.6 \pm 1.6$ & $7.3 \pm 2.4$ & $9 \pm 5.4^{\mathrm{bc}}$ & 0.001 \\
\hline Invasive ventilatory support before study (days) & $3 \pm 1.7$ & $4.4 \pm 3$ & $10.6 \pm 7$ & 0.07 \\
\hline Simplified Acute Physiology Score II (SAPS II) & $33 \pm 9$ & $34 \pm 6$ & $48 \pm 14^{\mathrm{cd}}$ & 0.1 \\
\hline Mortality (\%) & 10 & 30 & 80 & 0.02 \\
\hline
\end{tabular}

Analysis of the groups based on the three consequent weeks of the time elapsed between the hospital admission and the study day. Normal distribution for continuous variables has been tested with the Shapiro-Wilk test. Differences between groups, for normally distributed variables, are tested with one-way repeated measure ANOVA and Tukey post-hoc test for multiple comparisons, while non-normally distributed variables with the non-parametric Kruskal-Wallis test. All the values refer to supine-5 position otherwise specified. Chi-square test of independence was used to test significance in case of frequency count

a Patients here defined as non responders to prone position when Delta $\mathrm{PaO}_{2} / \mathrm{FiO}_{2} \geq 20 \mathrm{mmHg}$

b $p<0.05$ on ANOVA: post_hoc test significant between I week and II week

c $p<0.05$ on ANOVA: post_hoc test significant between I week and III week

d $p<0.05$ on ANOVA: post_hoc test significant between II week and III week

observed a limited rectruitability and poor responses to PEEP $[2,27,28]$. The mechanism underlying these different responses, however, are still unclear.

In our population cohort, two phenomena appeared to occur simultaneously when the airway pressure was raised from supine- 5 to supine-35. On the one hand, all the atelectasis present in supine- 5 disappeared in supine-35 (as per our definition). For an unchanged perfusion of the previous atelectatic tissue, this phenomenon per se should promote an increase of $\mathrm{PaO}_{2} /$ $\mathrm{FiO}_{2}$. On the other hand, perfusion diverted from previously atelectatic tissue to consolidated tissue, almost doubling its apparent perfusion ratio (see Table 3).
These phenomena per se should lead to a decrease of $\mathrm{PaO}_{2} / \mathrm{FiO}_{2}$. Therefore, the changes of oxygenation during recruitment in these patients would depend by the balance between reopening of atelectasis and perfusion re-distribution.

Actually, the 12 patients who decreased their $\mathrm{PaO}_{2} /$ $\mathrm{FiO}_{2}$ after increasing the pressure to $35 \mathrm{cmH}_{2} \mathrm{O}$ had less atelectatic tissue fraction to be recruited than the patients who increased their $\mathrm{PaO}_{2} / \mathrm{FiO}_{2}(0.19 \pm 0.15$ vs $0.45 \pm 0.23 ; p=0.002$ ) (see Table $\mathrm{E} 1$ in supplement). In addition, the patients who decreased their $\mathrm{PaO}_{2} / \mathrm{FiO}_{2}$ had significantly higher consolidated tissue fraction (and increased perfusion at $35 \mathrm{cmH}_{2} \mathrm{O}$ ), than did the patients 
in whom the $\mathrm{PaO}_{2} / \mathrm{FiO}_{2}$ increased by that maneuver (consolidated tissue fraction $0.27 \pm 0.10$ vs $0.18 \pm 0.10$, $p=0.04$ ) (see Table E1 in supplement).

\section{The role of time}

Our data do not allow us to prove the role of time on COVID-19 pneumonia evolution. Indeed, our patients were not studied longitudinally. We observed, however, that the frequency of higher elastance, lower gas-volume, higher $\mathrm{PaCO}_{2}$ and ventilatory ratio, greater consolidation and lack of response to prone positioning and lung recruitment were higher in the patients studied in the third week rather than those studied in an earlier stage of the disease. As the prevalence of these changes are coherent with a progressive evolution of the lung pathology towards organizing pneumonia and "fibrosis-like" status [29-32] it is tempting to speculate that time had a key-role on the evolution of COVID-19 pneumonia. A decreased response with time to prone position and recruitment manoeuvers, however, has been previously described in COVID-19 and in non-COVID-19 ARDS [31, 33, 34].

\section{Limitations}

A major limitation of the study is the relatively small sample size of the study cohort and lack of longitudinal design, as different patients were studied at different time-points. Another limitation is the lack of formal randomization of the prone-supine positions sequence. These limitations were largely due to the complexity of the protocol and to logistical difficulties imposed by the pandemic. Indeed, this study was feasible only on days when sufficient workforce and COVID-19 dedicated CT were available. We should note, however, that we are dealing with a disease (similar in all patients, and not with a syndrome). Moreover, most prior advances in understanding the pathophysiology of ARDS by CT scan, such as the baby lung [35], density redistribution in prone position [15] and mechanisms of opening pressures [36-38] were achieved by carefully studying a similar or lower number of patients. In this study we used a total recruitment pressure of $35 \mathrm{~cm} \mathrm{H}_{2} \mathrm{O}$, compared with the standard value of $45 \mathrm{~cm} \mathrm{H}_{2} \mathrm{O}$. Despite our choice could lead to an overestimation of the consolidated tissue, we opted for this choice for safety reasons. Another shortcoming of this study is the lack of full hemodynamic data, which impedes more thorough understanding of gas-exchange variations. In addition, the $\mathrm{Qva} / \mathrm{Q}$ was measured using a central venous instead of a mixed venous blood.

\section{Conclusions}

In conclusion, we show that in unresolving COVID19 pneumonia, the respiratory mechanics and the gasexchange response to prone positioning and recruitment largely depend on the following two factors: perfusion dysregulation and the amount of consolidated tissue. As the amount of consolidated tissue was different among patients studied at different weeks since admission, it is possible that the respiratory treatment administered should be changed according to the stage of the disease.

\section{Supplementary Information}

The online version contains supplementary material available at https://doi. org/10.1007/s00134-021-06562-4.

\section{Author details \\ ${ }^{1}$ Department of Anesthesiology and Intensive Care Medicine, Azienda Ospedaliero-Universitaria di Parma, Parma, Italy. ${ }^{2}$ Department of Anesthesiol- ogy, University Medical Center Göttingen, Robert-Koch Straße 40, 37075 Göt- tingen, Germany. ${ }^{3}$ Radiology, Department of Medicine and Surgery, University of Parma, Parma, Italy. ${ }^{4}$ Department of Anesthesia, Intensive Care and Emer- gency - 'Città della Salute e della Scienza' Hospital, Turin, Italy. ${ }^{5}$ Department of Radiology, IRCCS Policlinico San Donato, San Donato Milanese, Italy. ${ }^{6}$ Department of Adult Critical Care, Guy's and St Thomas' NHS Foundation Trust, Health Centre for Human and Applied Physiological Sciences, London, UK. ${ }^{7}$ Department of Pulmonary and Critical Care Medicine, University of Minnesota and Regions Hospital, St. Paul Minnesota, USA. ${ }^{8}$ Department of Anesthesiology and Intensive Care, IRCCS San Raffaele Scientific Institute, Milan, Italy.}

\section{Acknowledgements}

We are in great debt with Maria Luisa Caspani for her invaluable contribution to this study. We thank Sartorius AG (Otto-Brenner-Straße 20, 37079, Göttingen, Germany) for two unrestricted grants for research in respiratory medicine.

\section{Author contributions}

Conception and design: SR, MMP, LG; Data acquisition: NS, LM, PC, PB, ES; Analysis and interpretation: MMP, MB, FR, MB, SG, IS, MC, PH, PP, SL, FC; Drafting the manuscript for important intellectual content: LS, KM, MQ, LC, JJM, LG.

\section{Funding}

Open Access funding enabled and organized by Projekt DEAL.

Availability of data and material

Database may be available after request to the corresponding author.

Code availability

Not applicable.

\section{Declarations}

\section{Conflicts of interest}

The authors have no competing interests to disclose.

\section{Ethics approval and consent to participate}

Protocol number of the ethical committee: 779/2020/OSS/AOUPR. The informed consent was obtained using a remote process after discharge.

\section{Open Access}

This article is licensed under a Creative Commons Attribution-NonCommercial 4.0 International License, which permits any non-commercial use, sharing, adaptation, distribution and reproduction in any medium or format, as long as you give appropriate credit to the original author(s) and the source, provide a link to the Creative Commons licence, and indicate if changes were made. The images or other third party material in this article are included in the article's Creative Commons licence, unless indicated otherwise in a credit line to the material. If material is not included in the article's Creative Commons licence and your intended use is not permitted by statutory regulation or exceeds the permitted use, you will need to obtain permission directly from the copyright holder. To view a copy of this licence, visit http://creativecommons.org/licen ses/by-nc/4.0/. 


\section{Publisher's Note}

Springer Nature remains neutral with regard to jurisdictional claims in published maps and institutional affiliations.

Received: 8 September 2021 Accepted: 19 October 2021 Published online: 26 November 2021

\section{References}

1. Grasselli G, Tonetti T, Protti A, Langer T, Girardis M, Bellani G, Laffey J, Carrafiello G, Carsana L, Rizzuto C, Zanella A, Scaravilli V, Pizzilli G, Grieco DL, Di Meglio L, de Pascale G, Lanza E, Monteduro F, Zompatori M, Filippini C, Locatelli F, Cecconi M, Fumagalli R, Nava S, Vincent JL, Antonelli M, Slutsky AS, Pesenti A, Ranieri VM, Collaborators (2020) Pathophysiology of COVID-19-associated acute respiratory distress syndrome: a multicentre prospective observational study. Lancet Respir Med 8(12):1201-1208. https://doi.org/10.1016/S2213-2600(20)30370-2

2. Beloncle FM, Pavlovsky B, Desprez C, Fage N, Olivier PY, Asfar P, Richard JC, Mercat A (2020) Recruitability and effect of PEEP in SARS-Cov-2-associated acute respiratory distress syndrome. Ann Intensive Care 10(1):55. https://doi.org/10.1186/s13613-020-00675-7.PMID:32399901;PMCID: PMC7215140

3. Habashi NM, Camporota L, Gatto LA, Nieman G (2021) Functional pathophysiology of SARS-CoV-2-induced acute lung injury and clinical implications. J Appl Physiol (1985) 130:877-891

4. Chiumello D, Coppola S, Froio S, Mietto C, Brazzi L, Carlesso E, Gattinoni $L$ (2013) Time to reach a new steady state after changes of positive end expiratory pressure. Intensive Care Med 39:1377-1385

5. Gattinoni L, Caironi P, Cressoni M, Chiumello D, Ranieri VM, Ouintel M, Russo S, Patroniti N, Cornejo R, Bugedo G (2006) Lung recruitment in patients with the acute respiratory distress syndrome. N Engl J Med 354:1775-1786

6. Martinelli AW, Ingle T, Newman J, Nadeem I, Jackson K, Lane ND, Melhorn J, Davies HE, Rostron AJ, Adeni A, Conroy K, Woznitza N, Matson M, Brill SE, Murray J, Shah A, Naran R, Hare SS, Collas O, Bigham S, Spiro M, Huang MM, lqbal B, Trenfield S, Ledot S, Desai S, Standing L, Babar J, Mahroof R, Smith I, Lee K, Tchrakian N, Uys S, Ricketts W, Patel ARC, Aujayeb A, Kokosi M, Wilkinson AJK, Marciniak SJ (2020) COVID-19 and pneumothorax: a multicentre retrospective case series. Eur Respir J 56(5):2002697. https:// doi.org/10.1183/13993003.02697-2020

7. Herrmann P, Nguyen XP, Luecke T, Quintel M (2002) MALUNA 1.03e in Softwaretool zur analyse computertomographischer Schnittbilder del Lunge. Huethig Verlag, Heidelberg

8. Gattinoni L, Caironi P, Pelosi P, Goodman LR (2001) What has computed tomography taught us about the acute respiratory distress syndrome? Am J Respir Crit Care Med 164(9):1701-1711. https://doi.org/10.1164/ ajrccm.164.9.2103121

9. Cressoni M, Caironi P, Polli F, Carlesso E, Chiumello D, Cadringher P, Quintel M, Ranieri VM, Bugedo G, Gattinoni L (2008) Anatomical and functional intrapulmonary shunt in acute respiratory distress syndrome. Crit Care Med 36(3):669-675. https://doi.org/10.1097/01.CCM.00003 00276.12074.E1

10. Riley RL, Cournand A (1949) Ideal alveolar air and the analysis of ventilation-perfusion relationships in the lungs. J Appl Physiol 1:825-847

11. Pelosi P, Tubiolo D, Mascheroni D, Vicardi P, Crotti S, Valenza F, Gattinoni $L$ (1998) Effects of the prone position on respiratory mechanics and gas exchange during acute lung injury. Am J Respir Crit Care Med 157(2):387393. https://doi.org/10.1164/ajrccm.157.2.97-04023

12. Langer T, Brioni M, Guzzardella A, Carlesso E, Cabrini L, Castelli G, Dalla Corte F, De Robertis E, Favarato M, Forastieri A, Forlini C, Girardis M, Grieco DL, Mirabella L, Noseda V, Previtali P, Protti A, Rona R, Tardini F, Tonetti T, Zannoni F, Antonelli M, Foti G, Ranieri M, Pesenti A, Fumagalli R, Grasselli G, Group P-C (2021) Prone position in intubated, mechanically ventilated patients with COVID-19: a multi-centric study of more than 1000 patients. Crit Care 25:128

13. Gattinoni L, Taccone P, Carlesso E, Marini JJ (2013) Prone position in acute respiratory distress syndrome rationale, indications, and limits. Am J Respir Crit Care Med 188:1286-1293
14. Guerin C, Reignier J, Richard JC (2013) Prone positioning in the acute respiratory distress syndrome. N Engl J Med 369:980-981

15. Gattinoni L, Pesenti A, Carlesso E (2013) Body position changes redistribute lung computed-tomographic density in patients with acute respiratory failure: impact and clinical fallout through the following 20 years. Intensive Care Med 39:1909-1915

16. Cornejo RA, Diaz JC, Tobar EA, Bruhn AR, Ramos CA, Gonzalez RA, Repetto CA, Romero CM, Galvez LR, Llanos O, Arellano DH, Neira WR, Diaz GA, Zamorano AJ, Pereira GL (2013) Effects of prone positioning on lung protection in patients with acute respiratory distress syndrome. Am J Respir Crit Care Med 188:440-448

17. Mure M, Domino KB, Lindahl SG, Hlastala MP, Altemeier WA, Glenny RW (2000) Regional ventilation-perfusion distribution is more uniform in the prone position. J Appl Physiol (1985) 88:1076-1083

18. Richter T, Bellani G, Scott Harris R, Vidal Melo MF, Winkler T, Venegas JG, Musch G (2005) Effect of prone position on regional shunt, aeration, and perfusion in experimental acute lung injury. Am J Respir Crit Care Med 172:480-487

19. Lamm WJ, Graham MM, Albert RK (1994) Mechanism by which the prone position improves oxygenation in acute lung injury. Am J Respir Crit Care Med 150:184-193

20. Musch G, Layfield JD, Harris RS, Melo MF, Winkler T, Callahan RJ, Fischman AJ, Venegas JG (2002) Topographical distribution of pulmonary perfusion and ventilation, assessed by PET in supine and prone humans. J Appl Physiol (1985) 93:1841-1851

21. Nyren S, Mure M, Jacobsson H, Larsson SA, Lindahl SG (1999) Pulmonary perfusion is more uniform in the prone than in the supine position: scintigraphy in healthy humans. J Appl Physiol (1985) 86:1135-1141

22. Santamarina MG, Boisier D, Contreras R, Baque M, Volpacchio M, Beddings I (2020) COVID-19: a hypothesis regarding the ventilation-perfusion mismatch. Crit Care 24(1):395. https://doi.org/10.1186/s13054-020-03125-9

23. Si-Mohamed S, Chebib N, Sigovan M, Zumbihl L, Turquier S, Boccalini S, Boussel L, Mornex JF, Cottin V, Douek P (2020) In vivo demonstration of pulmonary microvascular involvement in COVID-19 using dual-energy computed tomography. Eur Respir J 56(4):2002608. https://doi.org/10. $1183 / 13993003.02608-2020$

24. Gattinoni L, Coppola S, Cressoni M, Busana M, Rossi S, Chiumello D (2020) COVID-19 does not lead to a "typical" acute respiratory distress syndrome. Am J Respir Crit Care Med 201(10):1299-1300. https://doi.org/10.1164/ rccm.202003-0817LE

25. Busana M, Giosa L, Cressoni M, Gasperetti A, Di Girolamo L, Martinelli A, Sonzogni A, Lorini L, Palumbo MM, Romitti F, Gattarello S, Steinberg I, Herrmann P, Meissner K, Quintel M, Gattinoni L (2021) The impact of ventilation-perfusion inequality in COVID-19: a computational model. J Appl Physiol 130(3):865-876. https://doi.org/10.1152/japplphysiol.00871. 2020

26. Ball L, Robba C, Maiello L, Herrmann J, Gerard SE, Xin Y, Battaglini D, Brunetti I, Minetti G, Seitun S, Vena A, Giacobbe DR, Bassetti M, Rocco PRM, Cereda M, Castellan L, Patroniti N, Pelosi P, group G (2021) Computed tomography assessment of PEEP-induced alveolar recruitment in patients with severe COVID-19 pneumonia. Crit Care 25:81

27. Chen L, Del Sorbo L, Grieco DL, Junhasavasdikul D, Rittayamai N, Soliman I, Sklar MC, Rauseo M, Ferguson ND, Fan E, Richard JM, Brochard L (2020) Potential for lung recruitment estimated by the recruitment-to-inflation ratio in acute respiratory distress syndrome. a clinical trial. Am J Respir Crit Care Med 201:178-187

28. Mauri T, Spinelli E, Scotti E, Colussi G, Basile MC, Crotti S, Tubiolo D, Tagliabue P, Zanella A, Grasselli G, Pesenti A (2020) Potential for lung recruitment and ventilation-perfusion mismatch in patients with the acute respiratory distress syndrome from coronavirus disease 2019. Crit Care Med 48:1129-1134

29. Barisione E, Grillo F, Ball L, Bianchi R, Grosso M, Morbini P, Pelosi P, Patroniti NA, De Lucia A, Orengo G, Gratarola A, Verda M, Cittadini G, Mastracci $L$, Fiocca R (2021) Fibrotic progression and radiologic correlation in matched lung samples from COVID-19 post-mortems. Virchows Arch 478:471-485

30. Shi H, Han X, Jiang N, Cao Y, Alwalid O, Gu J, Fan Y, Zheng C (2020) Radiological findings from 81 patients with COVID-19 pneumonia in Wuhan, China: a descriptive study. Lancet Infect Dis 20:425-434 
31. Gattinoni L, Bombino M, Pelosi P, Lissoni A, Pesenti A, Fumagalli R, Tagliabue M (1994) Lung structure and function in different stages of severe adult respiratory distress syndrome. JAMA 271(22):1772-1779

32. Nuckton TJ, Alonso JA, Kallet RH, Daniel BM, Pittet JF, Eisner MD, Matthay MA (2002) Pulmonary dead-space fraction as a risk factor for death in the acute respiratory distress syndrome. N Engl J Med 346:1281-1286

33. Patel BV, Haar S, Handslip R, Auepanwiriyakul C, Lee TM, Patel S, Harston JA, Hosking-Jervis F, Kelly D, Sanderson B, Borgatta B, Tatham K, Welters I, Camporota L, Gordon AC, Komorowski M, Antcliffe D, Prowle JR, Puthucheary Z, Faisal AA, United Kingdom C-ICUNSE (2021) Natural history, trajectory, and management of mechanically ventilated COVID-19 patients in the United Kingdom. Intensive Care Med 47:549-565

34. Grasso S, Mascia L, Del Turco M, Malacarne P, Giunta F, Brochard L, Slutsky AS, Marco Ranieri V (2002) Effects of recruiting maneuvers in patients with acute respiratory distress syndrome ventilated with protective ventilatory strategy. Anesthesiology 96:795-802

35. Gattinoni L, Pesenti A, Avalli L, Rossi F, Bombino M (1987) Pressurevolume curve of total respiratory system in acute respiratory failure.
Computed tomographic scan study. Am Rev Respir Dis 136(3):730-736. https://doi.org/10.1164/ajrccm/136.3.730

36. Crotti S, Mascheroni D, Caironi P, Pelosi P, Ronzoni G, Mondino M, Marini JJ, Gattinoni L (2001) Recruitment and derecruitment during acute respiratory failure: a clinical study. Am J Respir Crit Care Med 164(1):131-140. https://doi.org/10.1164/ajrccm.164.1.2007011

37. Cressoni M, Chiumello D, Algieri I, Brioni M, Chiurazzi C, Colombo A, Colombo A, Crimella F, Guanziroli M, Tomic I, Tonetti T, Luca Vergani G, Carlesso E, Gasparovic V, Gattinoni L (2017) Opening pressures and atelectrauma in acute respiratory distress syndrome. Intensive Care Med 43:603-611

38. Borges JB, Okamoto VN, Matos GF, Caramez MP, Arantes PR, Barros F, Souza CE, Victorino JA, Kacmarek RM, Barbas CS, Carvalho CR, Amato MB (2006) Reversibility of lung collapse and hypoxemia in early acute respiratory distress syndrome. Am J Respir Crit Care Med 174:268-278 